\title{
Physiological Traits and Metabolites of Cacao Seedlings Influenced by Potassium in Growth Medium
}

\author{
Yan-Mei Li ${ }^{1}$, Marshall Elson², Dapeng Zhang ${ }^{2}$, Richard C. Sicher ${ }^{3}$, Hang Li ${ }^{1}$, \\ Lyndel W. Meinhardt ${ }^{2}$, Virupax Baligar ${ }^{2 *}$
}

${ }^{1}$ College of Natural Resources and Environment/College of Computer and Information Science, Southwest University, Chongqing, China; ${ }^{2}$ Sustainable Perennial Crops Laboratory, USDA ARS, Beltsville, USA; ${ }^{3}$ Crop Systems and Global Change Laboratory, USDA ARS, Beltsville, USA.

Email: *vc.baligar@ars.usda.gov

Received March 21 ${ }^{\text {st }}, 2013$; revised April 20 ${ }^{\text {th }}, 2013$; accepted May $15^{\text {th }}, 2013$

Copyright (C) 2013 Yan-Mei Li et al. This is an open access article distributed under the Creative Commons Attribution License, which permits unrestricted use, distribution, and reproduction in any medium, provided the original work is properly cited.

\begin{abstract}
Cacao (Theobroma cacao L.) is of significant economic importance in several tropical countries but its yield potentials are low mainly because of poor soil fertility especially low levels of potassium (K). Cacao has a high demand for K to maintain healthy growth and production. Knowledge of $\mathrm{K}$ use in cacao will help the development of suitable crop management practices and will aid breeding varieties adapted to environments with a limited soil $\mathrm{K}$ supply. Using a plant growth chamber, we investigated the growth and physiological traits among three cacao varieties at three levels of growth medium K $\left(52,156\right.$, and $469 \mathrm{mg} \cdot$ plant $\left.^{-1}\right)$. Significant $\mathrm{K}$ effects were observed on growth traits including stem diameter, root length, chlorophyll $b$, and the ratio of chlorophyll $a / b$. Significant K effect was also found on carbohydrate metabolites, such as fructose, glucose, myo-inositol, raffinose and starch. However, no K effect was observed in other growth and physiological indicators, including biomass of seedling and net photosynthetic rate. There were significant genotype differences on seedling growth indicators, including stem diameter, stem height, total biomass, leaf biomass, leaf area, root length, chlorophyll $\mathrm{a}+\mathrm{b}$ and carotenoids. Genotype difference was also found on all measured carbohydrate and starch metabolites, except maltose and raffinose. Results of this study indicate that although K plays a critical role in cacao tree growth and productivity, cacao may be less sensitive to $\mathrm{K}$ deficiency during the seedling stage. The present results improved our understanding about $\mathrm{K}$ and plants interaction in cacao seedlings, which is useful for crop management and germplasm utilization.
\end{abstract}

Keywords: Cocao; Photosynthesis; Chlorophyll; Carbohydrates; Sugars

\section{Introduction}

Cacao (Theobroma cacao L.) is cultivated extensively as the source of cocoa butter and cocoa powder for the confectionery industry. Approximately four million tons of dry cacao beans are produced in a dozen or so tropical developing countries, where the livelihood of six million farmers depends on cacao production [1]. Despite the significant economic importance of cacao farming, the average yield of cacao is around $448 \mathrm{~kg} \mathrm{ha}^{-1}$ [2]. Numerous studies have tried to analyze the causes of low yield of cacao production $[3,4]$. Among the production constraints, poor soil fertility and lack of appropriate fertilization are considered the main contributors to the reduction of cacao yields [5]. As a perennial crop grown in the tropics, soils under cacao are often infertile and

\footnotetext{
${ }^{*}$ Corresponding author.
}

acidic due to long term cultivation with little or no fertilizer inputs, loss of nutrients through erosion and nutrient removal by the harvested crops [6].

The higher $\mathrm{K}$ requirement of cacao may be associated with its growth habit, large pod size and high $\mathrm{K}$ content in the pod husk $[5,6]$. Cacao responds well to $\mathrm{K}$ application and there are strong interactions between soil applied N, P and K and cacao yields [7]. On average, 1000 $\mathrm{kg}$ of green cacao beans contain about $33 \mathrm{~kg}$ of $\mathrm{K}[8]$. However levels of $\mathrm{K}$ applied vary depending with the age and type of cacao, and whether it is grown with or without shade [9].

Cacao soils average $4 \mathrm{mmol} \mathrm{K} \cdot \mathrm{kg}^{-1}$ soil $(0.4 \mathrm{meq}$ $\mathrm{K} / 100 \mathrm{~g}$ soil; or $156 \mathrm{mg} \mathrm{K} \cdot \mathrm{kg}^{-1}$ ) [6]. A good crop of three tons of dry cacao beans would normally remove over $170 \mathrm{~kg} \mathrm{~K} \cdot \mathrm{ha}^{-1}\left(77 \mathrm{mg} \cdot \mathrm{kg}^{-1}\right)$ [10]. General $\mathrm{K}$ fer- 
tilizer ecommendations for cacao are $85 \mathrm{~kg} \mathrm{~K} \mathrm{ha}^{-1} \cdot \mathrm{yr}^{-1}$ [11]. However, resource poor farmers of many cacao growing regions may not be able to apply this amount of $\mathrm{K}$-fertilizer. Cacao shows $\mathrm{K}$ deficiency at $0.2 \mathrm{meq} \mathrm{K} / 100$ $\mathrm{g}$ of soil $\left(78 \mathrm{mg} \cdot \mathrm{K} \cdot \mathrm{kg}^{-1}\right)$ [12]. However, severe $\mathrm{K}$ deficiency in cacao is very difficult to correct because of damage to the root system [10]. Therefore it is essential to have adequate level of $\mathrm{K}$ in the soil to maintain healthy cacao trees.

Information is very much lacking on the nutrient management for cacao. Deficiencies and toxicities of essential nutrients in soil induce a series of physiological alterations in plants including deficiencies of essential nutrients, inhibition of photosynthesis, alteration in carbon allocations, changes in water relations, damage to membranes and altered enzyme activities [13-15]. Therefore, the objective of this study was to evaluate the effects of deficit to excess levels of soil $\mathrm{K}$ on growth and physiological traits and metabolites (starch, carbohydrates) of three cacao genotypes.

\section{Materials and Methods}

\subsection{Cacao Genotypes and Seedling Preparation}

Well-developed cacao pods of three genotypes (Amelonado, EET-400 and ICS 95) were received from Dr. Brian Irish, USDA-ARS-Tropical Agriculture Research Station, Mayaguez, Puerto Rico. Among the three genotypes, Amelonado is a typical lower Amazon Forastero selection originating from Brazil [16,17]. EET-400 is a hybrid progeny of a cross between an Upper Amazon Forastero mother originating from Napo River, Ecuador and an unknown father. ICS 95 is a Trinitario type clone selected from Trinidad [16]. These three genotypes have been widely distributed in most of the cacao producing countries and commonly used as parental clones in cacao breeding programs. Seeds were separated from the pods, the seed coats were removed and the seeds were soaked in $10 \%$ chlorine bleach for two minutes and washed twice in sterile Deionized-water (DI), then soaked in $90 \%$ ethanol for two minutes and washed twice in sterile DI-water to remove any microbial contamination. Seeds were allowed to germinate on moist sterile filter paper under laboratory conditions at $25^{\circ} \mathrm{C}\left( \pm 2^{\circ} \mathrm{C}\right)$ for 48 hours until radicles emerged.

\subsection{Growth Conditions}

Seeds with at least a one $\mathrm{mm}$ radical were transplanted to plastic pots containing $3 \mathrm{~kg}$ of DI-water washed Ottawa sand. Plants were grown in a climatically controlled EGC growth room (Environmental Growth Chambers, Chagrin Falls, OH, Model GR-48). Twenty VHO fluorescent lamps (F96T12/CW-1500) and six 60-watt incandescent lamps in each of two height-adjustable canopies provided $14 \mathrm{~h} \cdot \mathrm{day}^{-1}$ of $600 \mu \mathrm{mol} \mathrm{m} \mathrm{m}^{-2} \cdot \mathrm{s}^{-1}$ photosynthetic photon flux density (PPFD) at the plant canopy. The day temperature of the growth chamber was $30^{\circ} \mathrm{C}$ with $75 \% \mathrm{RH}$ and night temperature was $28^{\circ} \mathrm{C}$ at $75 \% \mathrm{RH}$. Ambient $\mathrm{CO}_{2}$ was maintained at $400 \mathrm{~cm}^{3} \cdot \mathrm{m}^{-3}$.

\subsection{Sand and Nutrition Solution Growth Medium}

For the first 20 days, each container was surface irrigated on every Monday with $100 \mathrm{ml}$ of $1.5 \mathrm{mM} \mathrm{Ca}\left(\mathrm{NO}_{3}\right)_{2} \cdot 4 \mathrm{H}_{2} \mathrm{O}$ solution. On the 21 st day after transplant, nutrient solution was used to provide essential nutrients and the desired $\mathrm{K}$ levels. Macro-and micronutrient concentrations of this solution were: $6.0 \mathrm{~N}, 1.5 \mathrm{Ca}, 1.7 \mathrm{Mg}, 1.0 \mathrm{P}$ $\left(\mathrm{mmol} \cdot \mathrm{L}^{-1}\right)$ and $110 \mathrm{Fe}, 20.6 \mathrm{~B}, 0.3 \mathrm{Zn}, 0.16 \mathrm{Cu}, 5.3 \mathrm{Mn}$ and $0.49 \mathrm{Mo}\left(\mu \mathrm{mol} \mathrm{L}{ }^{-1}\right)$. These nutrients were provided using salts of $\mathrm{Ca}\left(\mathrm{NO}_{3}\right)_{2} \cdot 4 \mathrm{H}_{2} \mathrm{O}, \mathrm{Ca}\left(\mathrm{H}_{2} \mathrm{PO}_{4}\right)_{2} \cdot \mathrm{H}_{2} \mathrm{O}$, $\mathrm{Mg}\left(\mathrm{NO}_{3}\right)_{2} \cdot 6 \mathrm{H}_{2} \mathrm{O}, \mathrm{NH}_{4} \mathrm{NO}_{3}, \mathrm{H}_{3} \mathrm{BO}_{3}, \mathrm{CuSO}_{4} \cdot 5 \mathrm{H}_{2} \mathrm{O}$, $\mathrm{MnSO}_{4} \cdot \mathrm{H}_{2} \mathrm{O},\left(\mathrm{NH}_{4}\right) 6 \mathrm{Mo}_{7} \mathrm{O}_{24} \cdot 4 \mathrm{H}_{2} \mathrm{O}, \mathrm{ZnSO}_{4} \cdot 7 \mathrm{H}_{2} \mathrm{O}$, and $\mathrm{Fe}$ DTPA (Sprint 330, Becker Underwood, Inc., Ames, IA). From this nutrient solution three treatment solutions (1.1, 3.3, $10.0 \mathrm{mM} \mathrm{K}$ ) were prepared using $\mathrm{K}_{2} \mathrm{SO}_{4}$ to provide the desired $\mathrm{K}$ treatments $\left(52,156,469 \mathrm{mg} \mathrm{K}\right.$ plant $^{-1}$ for 90 days growth). For all treatments, the solution $\mathrm{pH}$ was adjusted to 5.5 before addition to the sand. Plants were irrigated with $100 \mathrm{ml}$ of nutrient solution on every Monday and rinsed with $500 \mathrm{ml}$ of DI water every Friday to reduce salt buildup. Such an irrigation procedure was continued until the week before harvest.

\subsection{Physiological Traits}

One week before the final harvest, the net photosynthetic rate $\left(\mathrm{P}_{\mathrm{N}}\right)$, was measured from 9:00 am to 3:00 pm using a Li-Cor 6400 portable gas exchange system (Li-Cor Inc., Lincoln, NE). The sixth leaf from the apex was placed in the cuvette at PPFD of $600 \mu \mathrm{mol} \mathrm{m} \mathrm{m}^{-2} \cdot \mathrm{s}^{-1}$, temperature of $28^{\circ} \mathrm{C}$, carbon dioxide concentration of $400 \mathrm{~cm}^{3} \mathrm{~m}^{-3}$ and vapor pressure deficit (VPD) of $2.0-02.1 \mathrm{kPa}$. The leaf was allowed to equilibrate for $15 \mathrm{~min}$ and the rate of $\mathrm{P}_{\mathrm{N}}$ was recorded. Leaf pigments were determined by extracting two leaf discs $\left(0.785 \mathrm{~cm}^{2}\right.$ each, obtained from the sixth leaf from the apex of the orthotropic axis) for 24 h with $5 \mathrm{ml}$ DMSO [18]. Chlorophyll a (Chl a), Chl b, $\mathrm{Chl}(\mathrm{a}+\mathrm{b})$ and carotenoid contents were determined spectrophotometrically according to Lichtenthaler [19] and Chappelle et al. [20].

\subsection{Sand and Nutrition Solution Growth Medium}

The final harvest was completed 90 days after initiation of the K treatments. Stem height, stem diameter, leaf count, fresh biomass of stems and leaves, and total leaf area (Li-Cor Model 3100 leaf area meter, Li-Cor Inc., 
Lincoln, NE) were measured. Stems and leaves were washed in DI-water; blotted dry, freeze-dried and the dry biomasses were recorded. Roots were removed from the growth medium and washed in DI-water. The fresh root biomasses and root lengths (Comair Root Length Scanner, Hawker de Haviland, Melbourne, Victoria, Australia) were recorded. Roots were oven-dried at $70^{\circ} \mathrm{C}$ for 5 days and dry root biomass was recorded. Based on the above measured growth traits, other growth parameters were calculated, such as Leaf/shoot ratio (L/S) and Root/shoot ratio $(\mathrm{R} / \mathrm{S})$.

\subsection{Metabolites}

Freeze dried leaf tissue $(30 \mathrm{mg})$ was placed in $2 \mathrm{ml}$ SealRite conical microcentrifuge tubes (USA Scientific, Ocala, FL) containing a $6.4 \mathrm{~mm}$ diameter ceramic bead (MP Biomedicals, Santa Ana, CA). Leaf tissue was pulverized at room temperature with four to six $30 \mathrm{~s}$ bursts in a TissueLyser II bead mill (Qiagen, Valencia, CA). The pulverized tissue was extracted with $1.4 \mathrm{ml}$ of $70 \%$ methanol containing $25 \mu \mathrm{l}$ of an internal standard (2 $\mathrm{mg} \cdot \mathrm{ml}^{-1}$ ribitol). The samples were incubated at $45^{\circ} \mathrm{C}$ for $5 \mathrm{~min}$ in a heat block and centrifuged at $15,600 \mathrm{~g}$ for 4 min in an Eppendorf 5415D centrifuge (Eppendorf North America, Hauppauge, NY). The supernatant fraction was transferred to $15 \mathrm{ml}$ plastic centrifuge tubes and the pellets were re-extracted with $1.4 \mathrm{ml}$ of $70 \%$ methanol. The supernatants were combined after centrifugation as above and stored at $-20^{\circ} \mathrm{C}$ until use. The pellets were washed twice with $1 \mathrm{ml}$ of $100 \%$ methanol and air dried overnight for starch analysis.

To determine the starch content, $1 \mathrm{ml}$ of water was added to the dried pellet fraction. A $0.25-\mathrm{ml}$ aliquot of the resuspended pellet was transferred to new $1.5 \mathrm{ml}$ tubes and the samples were incubated at $60^{\circ} \mathrm{C}$ in a waterbath for $15 \mathrm{~min}$. The temperature was increased to $100^{\circ} \mathrm{C}$ and the samples were boiled for $45 \mathrm{~min}$. A starch digesting enzyme solution $(0.25 \mathrm{ml})$ containing $15 \mathrm{mg}$ $\mathrm{ml}^{-1} \alpha-\beta$ amylase and $0.15 \mathrm{mg} \cdot \mathrm{ml}^{-1}$ of amyloglucosidase in $0.2 \mathrm{M} \mathrm{Na}$-Acetate ( $\mathrm{pH}$ 5.0) was added to each starch sample. Leaf starch was digested for $4 \mathrm{~h}$ at $50^{\circ} \mathrm{C}$ and then the digests were stored at $-20^{\circ} \mathrm{C}$. The starch content was determined in a Shimadzu UV-2101PC Spectrophotometer (Shimadzu North America, Columbia, MD) with a CPS controller $\left(25^{\circ} \mathrm{C}\right)$. The reaction solution contained $50 \mathrm{mM}$ HEPES and $1 \mathrm{mM} \mathrm{MgCl}_{2}$ (pH 7.6), $0.8 \mathrm{mM}$ ATP, $0.4 \mathrm{mM}$ NADP,$+ 1 \mathrm{IU}$ of hexokinase and $10 \mu \mathrm{l}$ of sample. Reactions were initiated with $10 \mu \mathrm{l}$ of glucose-6-P dehydro-genase $\left(0.2 \mathrm{IU} \cdot \mu \mathrm{l}^{-1}\right.$, Sigma G7877) and the change in absorbance was determined at $340 \mathrm{~nm}$. Starch content was determined using the formula:

$$
\text { glc/mg DW }=(A 340 / 6.22)\left(V_{\text {tot }} / V_{\text {assav }}\right)(1.0 \mathrm{ml} / \mathrm{DW})(1)
$$

Soluble carbohydrates were measured by gas chromatography coupled to mass spectrometry as described by Roessner et al. [21]. A 20- $\mu 1$ aliquot of each methanol extract was dried overnight in a vacuum desiccator. Dried samples were resuspended in $0.1 \mathrm{ml}$ of $20 \mathrm{mg} \mathrm{ml}^{-1}$ methoxyamine hydrochloride in pyridine and incubated in a waterbath at $30^{\circ} \mathrm{C}$ for $90 \mathrm{~min}$. The samples received $0.1 \mathrm{ml}$ of MSFTA ((N-methyl-N-(trimethylsilyl) trifluoroace-tamide) and were incubated at $37^{\circ} \mathrm{C}$ for $30 \mathrm{~min}$. The derivatized samples were separated by gas chromatography (GC System, HP 6890 Series) and the resultant ions were detected with a mass spectrometry detector (Agilent 5975C, Wilmington, DE). The volume injected was $1 \mu \mathrm{l}$. Separations were performed with a 30 $\mathrm{m} \times 0.25 \mathrm{~mm}$ Supelco SPB-50 column (Sigma-Aldrich, St. Louis, MO) with high-purity helium as the carrier gas at $1.2 \mathrm{ml} \cdot \mathrm{min}^{-1}$. The inlet temperature was $250^{\circ} \mathrm{C}$. The oven temperature was increased at $5^{\circ} \mathrm{C} \mathrm{min}^{-1}$ from $70^{\circ} \mathrm{C}$ to $310^{\circ} \mathrm{C}$ following a solvent delay of $8.5 \mathrm{~min}$. Total ion chromatograms were quantified using peak identification and calibration parameters in the Agilent MSD ChemStation software. Compounds quantified in the soluble carbohydrate fraction were sucrose, glucose, fructose, raffinose, myo-inositol, and maltose.

\subsection{Experimental Design}

A split plot design was used with genotypes as the main plots and $\mathrm{K}$ levels as the subplots and all experimental units were replicated 3 times. Data were subjected to analysis of variance using the general linear models (GLM) procedure of SAS (Ver. 9.3, SAS Institute, Cary, NC).

\section{Results and Discussion}

\subsection{Growth Traits}

The potassium level had significant effects on the stem diameter and root length of cacao (Table 1). When $\mathrm{K}$ levels increased, a significant increase in stem diameter was found in Amelonado and ICS 95, but not in EET-400. $\mathrm{K}$ and $\mathrm{Mg}$ were found to increase girth, number of branches/tree, and number of leaves/tree in coffee [22]. Increasing the $\mathrm{K}$ level significantly reduced the root length of all tested cacao genotypes. Significant K effects were not found for stem height and total dry biomass of cacao. Significant genotype effects were observed on the leaf biomass, leaf area, leaf/shoot ratio, stem diameter, stem height, root length and total dry biomass of cacao (Table 1). Among the three tested genotypes, Amelonado had the highest average stem diameter $(7.51 \mathrm{~mm})$ and stem height $(29.06 \mathrm{~cm})$. ICS 95 had the highest total dry biomass $(13.9 \mathrm{~g})$ and root length $(7480.3 \mathrm{~cm})$. Increasing potassium had no significant effect on the leaf biomass or leaf area of cacao (Table 1), which contradicts the litera- 
Table 1. Plant growth traits of three cacao genotypes influenced by soil K levels.

\begin{tabular}{|c|c|c|c|c|c|c|c|c|c|}
\hline Genotype & $\begin{array}{c}\mathrm{K} \text { level } \\
\left(\mathrm{mg} \cdot \text { plant }^{-1}\right)\end{array}$ & $\begin{array}{c}\text { Leaf } \\
\text { Biomass }(\mathrm{g})\end{array}$ & $\begin{array}{l}\text { Leaf Area } \\
\left(\mathrm{cm}^{2}\right)\end{array}$ & $\begin{array}{c}\text { Leaf/Shoot } \\
\text { Ratio }\end{array}$ & $\begin{array}{l}\text { Stem Diameter } \\
(\mathrm{mm})\end{array}$ & $\begin{array}{l}\text { Stem Height } \\
(\mathrm{cm})\end{array}$ & $\begin{array}{c}\text { Total Biomass } \\
\text { (g) }\end{array}$ & $\begin{array}{l}\text { Root Length } \\
\quad(\mathrm{cm})\end{array}$ & $\begin{array}{c}\text { Root/Shoot } \\
\text { Ratio }\end{array}$ \\
\hline \multirow[t]{3}{*}{ Amelonado } & 52 & 5.46 & 926.4 & 0.653 & 6.67 & 30.8 & 12.52 & 6921 & 0.519 \\
\hline & 156 & 5.51 & 904.9 & 0.652 & 7.55 & 29.3 & 13.85 & 5463 & 0.412 \\
\hline & 469 & 3.74 & 658.8 & 0.480 & 8.31 & 27.0 & 12.08 & 4731 & 0.550 \\
\hline \multirow[t]{3}{*}{ EET-400 } & 52 & 5.25 & 1114.3 & 0.715 & 6.42 & 25.5 & 10.87 & 6880 & 0.476 \\
\hline & 156 & 5.28 & 1126.8 & 0.693 & 6.42 & 24.5 & 11.00 & 5512 & 0.444 \\
\hline & 469 & 6.30 & 1354.6 & 0.722 & 6.76 & 24.8 & 12.37 & 5275 & 0.433 \\
\hline \multirow[t]{3}{*}{ ICS 95} & 52 & 5.99 & 1169.4 & 0.711 & 6.42 & 24.0 & 13.28 & 7987 & 0.585 \\
\hline & 156 & 6.99 & 1408.2 & 0.704 & 7.08 & 23.3 & 14.68 & 7668 & 0.478 \\
\hline & 469 & 6.5 & 1377.5 & 0.715 & 7.20 & 25.5 & 13.59 & 6786 & 0.500 \\
\hline \multicolumn{10}{|l|}{ Significance } \\
\hline Genotype (G) & & $* *$ & ** & ** & ** & ** & ** & ** & NS \\
\hline $\mathrm{K}$ level (K) & & NS & NS & NS & ** & NS & NS & ** & NS \\
\hline $\mathrm{G}^{*} \mathrm{~K}$ & & NS & NS & $* *$ & NS & NS & NS & NS & NS \\
\hline $\operatorname{LSD}_{0.05}$ & & 2.49 & 541.3 & 0.143 & 1.53 & 4.94 & 3.60 & 2007 & 0.248 \\
\hline
\end{tabular}

${ }^{* * *}$ significant at $\mathrm{P} \leq 0.05$ or 0.01 , respectively; $\mathrm{NS}=$ Non significant

ture for citrus [23] and coffee [24]. There were significant genotype effects on leaf biomass, leaf area and leaf/ shoot ratio. ICS 95 had the highest average leaf biomass $(6.49 \mathrm{~g})$ and leaf area $\left(1318.4 \mathrm{~cm}^{2}\right)$. Potassium had no effect on Leaf/Shoot Ratio, but the Amelonado genotype was significantly lower than the others. The interaction between $\mathrm{K}$ level and Genotype was significant because the mean Leaf/Shoot Ratio of Amelonado (0.480) in the high $\mathrm{K}$ level (469 $\mathrm{mg} \cdot$ plant $^{-1}$ ) was so much lower than the other treatments $(0.695)$.

A meta-analysis of 38 potassium fertilization experiments involving 26 forest tree species demonstrated that $\mathrm{K}$ addition tends to increase growth rates [25]. Enhancement of root growth and root branching on tropical plants due to increased $\mathrm{K}$ rates has also been recently reviewed by Wright et al. [26]. An alternative explanation for our results is that the presumed effect of plant growth, resulting from $\mathrm{K}$ increase, might not show on seedlings. While $\mathrm{K}$ deficiency was commonly reported in adult trees, young seedling plants may be less sensitive to low $\mathrm{K}$ concentration. The lower $\mathrm{K}$ concentration may be sufficient for cacao seedling growth. A similar result was reported by Rowan [27], who examined the effects of $\mathrm{K}$ on loblolly and slash pine seedlings in the southern US and concluded that addition of $\mathrm{K}$ fertilizer did not increase the survival and growth of pine seedlings in the nurseries.

In contrast to the lacking of $\mathrm{K}$ effect on a majority of the seedling growth traits, the present study showed significant genotype differences in growth traits (Tables 1 and 2). Among the three tested genotypes, ICS 95 had highest biomass averaged over the three $\mathrm{K}$ levels, leaf area and root length, whereas the Amelonado showed highest average stem diameter and stem height. Since the three genotypes belong to different germplasm groups, the observed differences could have resulted from variation of the genetic background. The three varieties have different geographical origins, thus may have different responses to changes in soil fertility, which would explain the highly significant genotype effect in most of the measured growth traits. This difference could be further explored for crop management and germplasm utilization. Selecting genotypes with lower K appetency would be preferred for a wider adaptability to a range of soils with varying $\mathrm{K}$ status.

\subsection{Chlorophyll, Carotenoid and Photosynthesis}

The soil potassium level had a significant effect on Chl b and the $\mathrm{Chl} \mathrm{a} / \mathrm{b}$ ratio (Table 2). Increasing soil $\mathrm{K}$ increased the concentration of $\mathrm{Chl} b$ and decreased the Chl $\mathrm{a} / \mathrm{b}$ ratio. However, the $\mathrm{K}$ level had no effect on the concentration of $\mathrm{Chl}$ a or the concentration of $\mathrm{Chl} \mathrm{a}+\mathrm{b}$. Significant genotype effect was detected on $\mathrm{Chl} \mathrm{b}, \mathrm{Chl} \mathrm{a}+\mathrm{b}$, $\mathrm{Chl} \mathrm{a} / \mathrm{b}$ ratio and Carotenoids. Amelonado had the highest concentration of $\mathrm{Chl} \mathrm{a}, \mathrm{Chl} b$ and Carotenoids.

The soil $\mathrm{K}$ level had no influence on net photosynthesis rate $\left(\mathrm{P}_{\mathrm{N}}\right)$, which was unexpected. It is well known that when plants are $\mathrm{K}$ deficient, the rate of photosynthesis is reduced which contributes to slower growth and development. $\mathrm{K}$ deficient plants (Arabidopsis) have reduced carbon fixation and assimilate export [28]. 
Table 2. Chlorophyll, Carotenoids and Photosynthesis in three cacao genotypes influenced by soil K levels.

\begin{tabular}{|c|c|c|c|c|c|c|c|}
\hline Genotype & $\begin{array}{c}\mathrm{K} \text { level } \\
\left(\mathrm{mg} \cdot \text { plant }^{-1}\right)\end{array}$ & $\begin{array}{l}\mathrm{Chl} \mathrm{a} \\
\left(\mathrm{g} \cdot \mathrm{m}^{-2}\right)\end{array}$ & $\begin{array}{l}\mathrm{Chl} \mathrm{b} \\
\left(\mathrm{g} \cdot \mathrm{m}^{-2}\right)\end{array}$ & $\begin{array}{c}\mathrm{Chl} \mathrm{a+b}+\mathrm{b} \\
\left(\mathrm{g} \cdot \mathrm{m}^{-2}\right)\end{array}$ & $\mathrm{Chl} \mathrm{a} / \mathrm{b}$ ratio & $\begin{array}{l}\text { Carotenoids } \\
\qquad\left(\mathrm{g} \mathrm{m}^{-2}\right)\end{array}$ & $\begin{array}{c}\mathrm{P}_{\mathrm{N}} \\
\left(\mu \mathrm{mol} \mathrm{CO} \mathrm{m}^{-2} \mathrm{~s}^{-1}\right)\end{array}$ \\
\hline \multirow[t]{3}{*}{ Amelonado } & 52 & 0.176 & 0.061 & 0.237 & 0.029 & 0.050 & 4.87 \\
\hline & 156 & 0.160 & 0.061 & 0.221 & 0.026 & 0.054 & 4.31 \\
\hline & 469 & 0.169 & 0.075 & 0.243 & 0.023 & 0.060 & 3.39 \\
\hline \multirow[t]{3}{*}{ EET-400 } & 52 & 0.151 & 0.051 & 0.202 & 0.030 & 0.046 & 4.30 \\
\hline & 156 & 0.140 & 0.051 & 0.192 & 0.027 & 0.045 & 3.99 \\
\hline & 469 & 0.136 & 0.061 & 0.197 & 0.022 & 0.037 & 3.54 \\
\hline \multirow[t]{3}{*}{ ICS 95} & 52 & 0.126 & 0.047 & 0.173 & 0.027 & 0.037 & 3.18 \\
\hline & 156 & 0.144 & 0.057 & 0.201 & 0.025 & 0.044 & 3.95 \\
\hline & 469 & 0.146 & 0.066 & 0.212 & 0.022 & 0.046 & 4.61 \\
\hline \multicolumn{8}{|l|}{ Significance } \\
\hline Genotype (G) & & NS & ** & ** & * & ** & NS \\
\hline K level (K) & & NS & $* *$ & NS & ** & NS & NS \\
\hline $\mathrm{G}^{*} \mathrm{~K}$ & & NS & NS & NS & NS & NS & NS \\
\hline $\operatorname{LSD}_{0.05}$ & & 0.054 & 0.016 & 0.069 & 0.004 & 0.019 & 2.21 \\
\hline
\end{tabular}

,** significant at $\mathrm{P} \leq 0.05$ or 0.01 , respectively. $\mathrm{NS}=$ Non significant.

Table 3. Concentrations of leaf metabolites (Carbohydrates, starch) of three cacao genotypes influenced by soil K levels.

\begin{tabular}{|c|c|c|c|c|c|c|c|c|}
\hline Genotype & $\begin{array}{c}\text { K level } \\
\left(\mathrm{mg} \mathrm{plant}^{-1}\right)\end{array}$ & Fructose & Glucose & myo-inositol & Sucrose & Maltose & Raffinose & Starch \\
\hline & & \multicolumn{6}{|c|}{$\mathrm{mg} \mathrm{g}^{-1}$} & $\mu \mathrm{mol} \mathrm{\textrm {mg } ^ { - 1 }}$ \\
\hline \multirow[t]{3}{*}{ Amelonado } & 52 & 11.33 & 8.03 & 1.38 & 206.5 & 0.785 & 2.286 & 0.344 \\
\hline & 156 & 8.34 & 6.10 & 1.37 & 217.8 & 0.770 & 1.856 & 0.361 \\
\hline & 469 & 4.63 & 3.43 & 0.97 & 186.3 & 0.746 & 1.708 & 0.304 \\
\hline \multirow[t]{3}{*}{ EET-400 } & 52 & 20.08 & 13.55 & 3.39 & 115.4 & 0.793 & 3.232 & 0.059 \\
\hline & 156 & 21.61 & 13.75 & 1.30 & 154.2 & 0.746 & 1.203 & 0.255 \\
\hline & 469 & 8.37 & 5.23 & 0.89 & 115.6 & 0.741 & 1.050 & 0.502 \\
\hline \multirow[t]{3}{*}{ ICS 95} & 52 & 15.16 & 10.79 & 1.39 & 128.4 & 0.779 & 2.188 & 0.372 \\
\hline & 156 & 14.24 & 8.07 & 1.15 & 135.3 & 0.772 & 1.446 & 0.484 \\
\hline & 469 & 5.66 & 3.23 & 1.02 & 167.7 & 0.762 & 1.370 & 0.498 \\
\hline \multicolumn{9}{|l|}{ Significance } \\
\hline Genotype (G) & & $* *$ & $*$ & * & $* *$ & NS & NS & * \\
\hline K level (K) & & $* *$ & $* *$ & $* *$ & NS & NS & $* *$ & * \\
\hline $\mathrm{G}^{*} \mathrm{~K}$ & & NS & NS & * & NS & NS & NS & * \\
\hline $\operatorname{LSD}_{0.05}$ & & 14.72 & 10.79 & 1.62 & 10.87 & 0.127 & 1.877 & 0.350 \\
\hline
\end{tabular}

,*** significant at $\mathrm{P} \leq 0.05$ or 0.01 , respectively. $\mathrm{NS}=$ Non significant

ATP dependent processes such as $\mathrm{P}_{\mathrm{N}}$ are slowed down by $\mathrm{K}$ deficiency $[29,30]$. In the current study genotypes were grown for 90 days and it appears that even the lowest level of soil $\mathrm{K}$ was not deficient enough to induce any major physiological changes in these plants. Growing these cacao genotypes longer than 90 days may have induced $\mathrm{K}$ deficiency at low soil $\mathrm{K}$ levels.

\subsection{Carbohydrate Metabolites and Starch}

Both genotype and soil $\mathrm{K}$ levels had significant effects on the concentrations of fructose, glucose, myo-inositol and starch (Table 3). In addition, genotypes had highly significant effects on the concentration of sucrose and soil $\mathrm{K}$ levels had highly significant effects on the concentration of raffinose. Overall, the higher $\mathrm{K}$ levels re- 
duced the concentrations of all the soluble sugars in the three cacao genotypes. Specifically, concentrations of fructose, glucose, myo-inositol, maltose and raffinose were higher at the lowest $\mathrm{K}$ level $\left(52 \mathrm{mg} \mathrm{K}\right.$ plant $\left.^{-1}\right)$. Among the three genotypes, EET-400 had the highest concentration of these metabolites followed by ICS 95 and then Amelonado. Nonetheless, the effect of $\mathrm{K}$ was not significant on sucrose or maltose. Contrasting to the above metabolites, starch in cacao leaves increased at the higher K level (Table 3). Starch contents (averaged over the three genotypes) were $0.258,0.367$ and $0.437(\mu \mathrm{mol}$ $\left.\mathrm{mg}^{-1}\right)$ at 52,156 and $469\left(\mathrm{mg} \mathrm{K}\right.$ plant $\left.^{-1}\right)$, respectively.

The observed changes of carbohydrate metabolites and starch in cacao seedlings in response to $\mathrm{K}$ levels is compatible with previously reported experiments in coffee [31] and citrus [23], where increased $\mathrm{K}$ application has been shown to increase starch content and reduce soluble sugar accumulation. This change suggests that $\mathrm{K}$ is essential for the conversion of sugars to starch in cacao seedlings. Reduced $\mathrm{K}$ levels may affect the activity of enzymes associated with carbohydrate metabolism, i.e. starch synthase in the same way as reported in soybean [32] and spinach [33]. The effect of $\mathrm{K}$ on carbohydrate metabolites and starch indicates that $\mathrm{K}$ application caused significant physiological changes in these cacao seedlings, both visible and invisible. However in spite of these significant changes, cacao seedlings may still be able to obtain satisfactory vegetative growth. When adequate cacao yield and bean quality are put into consideration, the requirement for optimum $\mathrm{K}$ would be very different and, thus, needs further investigation.

\section{Acknowledgements}

The authors would like to thank Brian Irish of TARS, USDA-ARS for providing experimental materials, Jinyoung Barnaby and Mary Strem of SPCL, USDA-ARS for assistance in lab work, Guolu Liang and Qigao Guo of Southwest University, P. R. China for valuable discussion and critical reading of the manuscript. The authors would also like to thank China Scholar Council, Ministry of Education, China for providing a scholarship for YanMei Li.

\section{REFERENCES}

[1] World Cocoa Foundation, "Cocoa Production," 2012. http://www.worldcocoafoundation.org

[2] FAOSTAT, "Food and Agricultural Commodities Production," FAO Statistical Databases, 2010. http://faostat.fao.org/default.aspx

[3] M. Franzen and M. B. Mulder, "Ecological, Economic and Social Perspectives on Cocoa Production Worldwide," Biodiversity and Conservation, Vol. 16, No. 13, 2007, pp. 3835-3849. doi:10.1007/s10531-007-9183-5

[4] E. N. A. Dormon, A. V. Van Huis, C. Leeuwis, D. Obeng-
Ofori and O. Sakyi-Dawson, "Causes of Low Productivity of Cocoa in Ghana: Farmers' Perspectives and Insights from Research and the Socio-political Establishment," NJAS-Wageningen Journal of Life Sciences, Vol. 52, No. 3-4, 2004, pp. 237-259. doi:10.1016/S1573-5214(04)80016-2

[5] G. A. R. Wood and R. A. Lass, "Cocoa," 4th Edition, Longman, New York, 2001. doi:10.1002/9780470698983

[6] A. E. Hartemink, "Nutrient Stocks, Nutrient Cycling, and Soil Changes in Cocoa Ecosystems: A Review," $\mathrm{Ad}$ vances in Agronomy, Vol. 86, 2005, pp. 227-253. doi:10.1016/S0065-2113(05)86005-5

[7] Y. Ahenkorah, B. J. Halm, M. R. Appiah, G. S. Akrofi and J. E. K. Yirenkyi, "Twenty Years' Results from a Shade and Fertilizer Trial on Amazon Cocoa (Theobroma cacao) in Ghana," Expimental Agriculture, Vol. 23, No. 1, 1987, pp. 31-39. doi:10.1017/S0014479700001101

[8] K. C. Willson, "Coffee, Cocoa and Tea," CABI Publishing, Wallingford, 1999.

[9] A. A. Adeyemi, "Effective Intercropping Systems for Young Cocoa," Tropical Science, Vol. 39, No. 1, 1999, pp. 1-10.

[10] H. R. von Uexkull and A. Cohen, "Potassium Requirements of Some Tropical Tree Crops (Oil Palm, Coconut Palm, Rubber, Coffee, Cocoa) and Cotton," In: IPI Research Topics, No. 7: Potassium Requirements of Crops, International Potash Institute, Bern, 1980, pp. 71-104.

[11] F. Hardy, "Cacao Manual," Inter-America Institute of Agricultural Science, Turriabla, 1960.

[12] P. Cabala-Rosand, M. B. M. Santana and C. J. L. de Santana. "Cacao," In: D. L. Plucknett and H. B. Sprague, Eds., Detecting Mineral Nutrient Deficiencies in Tropical and Temperate Crops, Westview Press, Boulder, 1989, pp. 409-425.

[13] H. Marschner, "Mineral Nutrition of Higher Plants," 2nd Edition, Academic Press, New York, 1995.

[14] V. C. Baligar, N. K. Fageria and Z. L. He, "Nutrient Use Efficiency in Plants," Communications in Soil Science and Plant Analysis, Vol. 32, No. 7-8, 2001, pp. 921-950. doi:10.1081/CSS-100104098

[15] K. Mengel and E. A. Kirkby, "Principles of Plant Nutrition," 5th Edition, Kluwer Academic Publishers, Dordrecht, 2001. doi:10.1007/978-94-010-1009-2

[16] B. G. D. Bartley, "The Genetic Diversity of Cacao and Its Utilization," CABI Publishing, Wallingford, 2005. doi:10.1079/9780851996196.0000

[17] J. C. Motamayor, P. Lachenaud, J. W. da Silva e Mota, R. Loor, D. N. Kuhn, J. S. Brown and R. J. Schnell, "Geographic and Genetic Population Differentiation of the Amazonian Chocolate Tree (Theobroma cacao L.)," PLoS ONE, Vol. 3, No. 10, 2008, e3311. doi:10.1371/journal.pone.0003311

[18] J. D. Hiscox and G. F. Israelstem, "A Method for Extraction of Chlorophyll from Leaf Tissue without Maceration," Canadian Journal of Botany, Vol. 57, No. 12, 1979, pp. 1332-1334. doi:10.1139/b79-163

[19] H. K. Lichtenthaler, "Chlorophylls and Carotenoids: Pigments of Photosynthetic Biomembranes," Methods in En- 
zymology, Vol. 148, 1987, pp. 350-382. doi:10.1016/0076-6879(87)48036-1

[20] E. W. Chappelle, M. S. Kim and J. E. McMurtrey III, "Ratio Analysis of Reflectance Spectra (RARS): An Algorithm for the Remote Estimation of the Concentration of Chlorophyll A, Chlorophyll B, and Carotenoids in Soybean Leaves," Remote Sensing of Environment, Vol. 39, No. 3, 1992, pp. 239-247. doi:10.1016/0034-4257(92)90089-3

[21] U. Roessner, C. Wagner, J. Kopka, R. N. Trethewey and L. Willmitzer, "Technical Advance: Simultaneous Analysis of Metabolites in Potato Tuber by Gas Chromatography-Mass Spectrometry," Plant Journal, Vol. 23, No. 1, 2000, pp. 131-142.

doi:10.1046/j.1365-313x.2000.00774.x

[22] B. A. Oruko and G. M. Gatitu, "The Role of Potassium and Magnesium in the Nutrition and Yield of Coffea arabica L.," Kenya Coffee, Vol. 44, No. 515, 1979, pp. 15- 24.

[23] R. Lavon, E. E. Goldschmidt, R. Salomon and A. Frank, "Effect of Potassium, Magnesium, and Calcium Deficiencies on Carbohydrate Pools and Metabolism in Citrus Leaves," Journal of American Society for Horticultural Science, Vol. 120, No. 1, 1995, pp. 54-58.

[24] A. J. Tesha and D. Kumar, "Effects of Soil Moisture, Potassium and Nitrogen on Mineral Absorption and Growth of Coffea arabica L.," Turrialba, Vol. 29, No. 3, 1979, pp. 213-218.

[25] C. E. Tripler, S. S. Kaushal, G. E. Likens and M. T. Walter, "Patterns in Potassium Dynamics in Forest Ecosystems," Ecology Letters, Vol. 9, No. 4, 2006, pp. 451-466. doi:10.1111/j.1461-0248.2006.00891.x

[26] S. J. Wright, J. B. Yavitt, N. Wurzburger, B. L. Turner, E. V. J. Tanner, E. J. Sayer, L. S. Santiago, M. Kaspari, L. O.
Hedin, K. E. Harms, M. N. Garcia and M. D. Corre, "Potassium, Phosphorus or Nitrogen Limit Root Allocation, Tree Growth and Litter Production in a Lowland Tropical Forest," Ecology, Vol. 92, No. 8, 2011, pp. 1616-1625. doi:10.1890/10-1558.1

[27] S. J. Rowan, "Effects of Potassium Fertilization in the Nursery on Survival and Growth of Pine Seedlings in the Plantation, Georgia Forest Research Paper No. 68," Georgia Forestry Commission, Macon, 1987.

[28] F. J. M. Maathuis and D. Sanders, "Mechanisms of Potassium Absorption by Higher Plant Roots," Physiologia Plantarum, Vol. 96, No. 1, 1996, pp. 158-168. doi:10.1111/j.1399-3054.1996.tb00197.x

[29] T. R. Peoples and D. W. Koch, "Role of Potassium in Carbon Dioxide Assimilation in Medicago sativa L.," Plant Physiology, Vol. 63, No. 5, 1979, pp. 878-881. doi:10.1104/pp.63.5.878

[30] W. T. Pettigrew, "Potassium Deficiency Increases Specific Leaf Weights and Leaf Glucose Levels in FieldGrown Cotton," Agronomy Journal, Vol. 91, No. 6, 1999, pp. 962-968. doi:10.2134/agronj1999.916962x

[31] J. F. Carvajal, "Potassium Nutrition of Coffee," In: R. D. Munson, Ed., Potassium in Agriculture, Soil Science Society of America, Madison, Wisconsin, 1985, pp. 955-979.

[32] S. C. Huber, "Role of Potassium in Photosynthesis and Respiration," In: R. D. Munson, Ed., Potassium in Agriculture, Soil Science Society of America, Madison, Wisconsin, 1985, pp. 369-396.

[33] J. S. Hawker, H. Marschner and W. J. S. Downton, "Effects of Sodium and Potassium on Starch Synthesis in Leaves," Australian Journal of Plant Physiology, Vol. 1, No. 4, 1974, pp. 491-501. doi:10.1071/PP9740491 